\title{
Carbon Isotopic Evidence for Gas Hydrate Release and Its Significance on Seasonal Wetland Methane Emission in the Muli Permafrost of the Qinghai-Tibet Plateau
}

\author{
Xiaoqian Li ${ }^{1,2}$, Jianwei Xing ${ }^{2}$, Shouji Pang ${ }^{1,3, *}$, Youhai Zhu ${ }^{1,3}$, Shuai Zhang ${ }^{1,3}$, Rui Xiao ${ }^{1,3}$ and Cheng Lu ${ }^{1,3}$ \\ 1 The Key Laboratory of Unconventional Oil \& Gas Geology, China Geological Survey, Beijing 100083, China; \\ lixiaoqian@cug.edu.cn (X.L.); zhuyouhai@mail.cgs.gov.cn (Y.Z.); zhangshuai870517@163.com (S.Z.); \\ didaxr@163.com (R.X.); jaluch@126.com (C.L.) \\ 2 School of Environmental Studies, China University of Geosciences, Wuhan 430074, China; \\ 1201910330@cug.edu.cn \\ 3 Oil and Gas Survey, China Geological Survey, Beijing 100083, China \\ * Correspondence: psj0409@163.com
}

check for

updates

Citation: Li, X.; Xing, J.; Pang, S.; Zhu, Y.; Zhang, S.; Xiao, R.; Lu, C. Carbon Isotopic Evidence for Gas Hydrate Release and Its Significance on Seasonal Wetland Methane Emission in the Muli Permafrost of the Qinghai-Tibet Plateau. Int. J. Environ. Res. Public Health 2022, 19, 2437. https://doi.org/ 10.3390/ijerph19042437

Academic Editor: Leucio Rossi

Received: 12 January 2022

Accepted: 16 February 2022

Published: 20 February 2022

Publisher's Note: MDPI stays neutral with regard to jurisdictional claims in published maps and institutional affiliations.

Copyright: (c) 2022 by the authors. Licensee MDPI, Basel, Switzerland. This article is an open access article distributed under the terms and conditions of the Creative Commons Attribution (CC BY) license (https:/ / creativecommons.org/licenses/by/ $4.0 /)$.

\begin{abstract}
In order to determine the significant role of gas hydrate in seasonal wetland methane emission at the drilling-affected permafrost, the carbon isotopic monthly field monitoring of methane $\left(\mathrm{CH}_{4}\right)$, as well as carbon dioxide $\left(\mathrm{CO}_{2}\right)$, emitted from near-surface soil and a gas hydrate drilling well (DK-8) was conducted in the Muli permafrost of the Qinghai-Tibet Plateau. The methane source effused from the well DK-8 was calculated as $-25.9 \pm 1.4 \%$ and $-26.5 \pm 0.5 \%$, respectively, by the Keeling and Miller Tans plots, with the carbon isotope fractionation $\left(\varepsilon_{\mathrm{C}}\right)$ between $\mathrm{CO}_{2}$ and $\mathrm{CH}_{4}$ from $-25.3 \%$ to $-32.1 \%$. The carbon isotopic signatures are indicative of thermogenic origin associated with gas hydrate dissociation. The near-surface soil-emitted methane has ${ }^{13} \mathrm{C}_{\mathrm{CH} 4}$ values between $-52.0 \pm 1.2 \%$ and $-43.2 \pm 1.8 \%$ with the heaviest in December and the lightest in July. Further, the $\varepsilon_{C}$ values of near-surface soil-emitted gases were between $28.6 \%$ and $47.9 \%$, significantly correlated with the $\delta^{13} \mathrm{C}_{\mathrm{CH} 4}$ values. The linear correlation between $\varepsilon_{\mathrm{C}}$ and $\delta^{13} \mathrm{C}_{\mathrm{CH} 4}$ values indicated binary end-member of microbial and thermogenic sources control the seasonal variation of wetland methane emission. The thermogenically derived methane was identified as the dominant methane source in autumn and winter, compared with the increasing contribution of microbially derived methane in spring and summer. The finding provides reliable evidence for gas hydrate release on the seasonal wetland methane emission in the Muli permafrost affected by drilling activities. The combined application of $\varepsilon_{\mathrm{C}}$ and $\delta^{13} \mathrm{C}_{\mathrm{CH} 4}$ to distinguish thermogenic from biogenic methane is well established and powerful in complex environments, which can provide an improved constraint on source apportionment for wetland emitted methane in the permafrost of the Qinghai-Tibet Plateau.
\end{abstract}

Keywords: carbon isotopic signature; gas hydrate; wetland methane emission; permafrost; QinghaiTibet Plateau

\section{Introduction}

Methane $\left(\mathrm{CH}_{4}\right)$ is an important greenhouse gas that provides the second-largest contribution to historical global warming, with stronger climate warming potential than carbon dioxide $\left(\mathrm{CO}_{2}\right)$ [1]. Global atmospheric methane concentrations have increased rapidly since 2007 at a renewed growth rate of $6.9 \pm 2.7 \mathrm{ppb} \mathrm{yr}^{-1}$ [2]. Wetland methane emissions, the largest natural source in the global $\mathrm{CH}_{4}$ budget, play an emerging role in driving 21st-century climate change [3]. The carbon pools in permafrost regions are large reservoirs susceptible to climate change and can drive positive feedback to climate warming [4-8]. Methane emission in the thawing permafrost is key to the greenhouse gas budget on climate-relevant timescales [9]. Therefore, the wetland methane emission process strongly associated with wetland carbon cycling in permafrost regions is of great significance to understanding climate feedback and mitigating global warming. 
The Qinghai-Tibet Plateau is the largest high-altitude permafrost region on Earth, with a wetland area covering approximately $130,000 \mathrm{~km}^{2}$ [10]. In addition, substantial amounts of soil organic carbon [11-13] and thermogenic hydrocarbons in gas hydrates [14-16] are stored in the Qinghai-Tibet Plateau. Compared with conventional peat wetlands, the alpine wetlands emission of the Qinghai-Tibet Plateau is unique and complex under global climate warming [17], which is highly sensitive to temperature change [18-20], thawing of permafrost [21-23], and the destabilization of gas hydrates [24-26]. As a result, the average atmospheric methane content in the Waliguan of the Qinghai-Tibet Plateau was reported as $1931 \pm 3 \mathrm{ppb}$ in 2019 [27] higher than the global average content (1877 \pm 2 ppb), with an annual increasing rate of $7.7 \mathrm{ppb}$ during the past ten years [27] compared to the global annual increasing rate of $7.3 \mathrm{ppb}$. Source identification of wetland methane emission is an important issue for understanding the processes and mechanisms of wetland methane emission and carbon cycling in the Qinghai-Tibet Plateau.

Previous studies asserted that the source of wetland methane emission above the Muli gas hydrate reservoir in the Qilian Mountain permafrost could be hydrocarbon gases released by subterranean gas hydrates $[14,26,28]$. However, whether dissociation of gas hydrate when the $\mathrm{p}-\mathrm{T}$ condition changes caused by natural process or anthropogenic activities has a significant impact on the wetland methane emission has not been fully constrained. The methane derived from gas hydrate release can effuse towards the nearsurface soil through micro-seepage [29] and may have an impact on the surface carbon circulation system, forming a new source of methane emission from wetland soils in permafrost regions. Recent research of 42 monitoring sites over an area of $3 \mathrm{~km}^{2}$ in the Muli permafrost [30] reported some $\delta^{13} \mathrm{C}_{\mathrm{CH} 4}$ values of free gas in the near-surface soil were between $-48.0 \%$ and $-42.2 \%$, which indicated methane of thermogenic origin. The relationship between the emission by soils and effusion from gas hydrates was determined through correlation analyses of soil-adsorbed hydrocarbons [30,31]. Nevertheless, it still lacks direct and sufficient evidence for the effect of methane from gas hydrate dissociation on soil methane emission.

The distinct $\delta^{13} \mathrm{C}_{\mathrm{CH} 4}$ signatures are frequently used as a useful constraint to distinguish between thermogenic and biogenic methane sources. The thermogenic methane is generally enriched in ${ }^{13} \mathrm{C}$ compared with biogenic methane that has $\delta^{13} \mathrm{C}_{\mathrm{CH}}$ values more negative than $-50 \%$ and up to $-100 \%$ [32]. However, situations, such as the mixing of different natural gases or where extreme substrate depletion and $\mathrm{CH}_{4}$ consumption by oxidation, could produce ambiguous methane isotope signals [32,33]. The carbon isotope separation $\left(\varepsilon_{\mathrm{C}}\right.$ ) between $\mathrm{CH}_{4}$ and $\mathrm{CO}_{2}$ (defined by $\varepsilon_{\mathrm{C}} \approx \delta^{13} \mathrm{C}_{\mathrm{CO}}-\delta^{13} \mathrm{C}_{\mathrm{CH}}$ ) can remain consistent [32] despite large variations in the actual $\delta^{13} \mathrm{C}_{\mathrm{CH} 4}$ values and indicative of the particular methanogenic pathway. Accordingly, the combination of $\delta^{13} \mathrm{C}_{\mathrm{CH} 4}$ with $\varepsilon_{\mathrm{C}}$ values may reliably identify methane sources in complex environments.

The grid-monitoring results of near-surface soil samples at the gas hydrate reservoir region in the Muli permafrost [31] showed the intensive drilling site (DK-1,2,3,7,8,9, 12-13) was a unique area where the soil-emitted methane has lower $\delta^{13} \mathrm{C}_{\mathrm{CH} 4}(-65 \%$ to $-80 \%$ o $)$ in May whereas relatively higher $\delta^{13} \mathrm{C}_{\mathrm{CH} 4}(-54 \%$ to $-40 \%$ o $)$ in August and higher $\delta^{13} \mathrm{C}_{\mathrm{CH} 4}$ $(-38 \%$ to $-26 \%$ ) in October. Therefore, we conducted a twelve-month field monitoring of stable carbon isotopic compositions of $\mathrm{CO}_{2}$ and $\mathrm{CH}_{4}$ in the free gas of the near-surface soil at the above intensive drilling site in the Muli permafrost in 2017. The hydrocarbon gases emitted from one of the drilling wells (DK-8) were also monitored at the same time to determine their stable carbon isotopic signatures. This study is aimed to provide new evidence for gas hydrate release as a significant source of wetland methane emission in the Muli permafrost, to reveal the effect of gas hydrate release on wetland methane seasonal emission, and further, to imply the influence of anthropogenic activities, such as drilling, on wetland methane emission in the permafrost of the Qinghai-Tibet Plateau. 


\section{Materials and Methods}

\subsection{Study Area}

The study area is located in the Muli permafrost of the Qilian Mountains in the northeastern margin of the Qinghai-Tibet Plateau (Figure 1a,b), with an altitude of approximately $4000-4300 \mathrm{~m}$ and an annual average temperature of $-5.1{ }^{\circ} \mathrm{C}$. The wetland ecosystem is dominated by alpine meadow, which is influenced by permafrost freezing and thawing driven by seasonal temperature variation. The alpine-typed permafrost covers an area of $1 \times 10^{5} \mathrm{~km}^{2}$ in the Qilian Mountains, with a thickness regionally ranging from 60 to $95 \mathrm{~m}$ and an active layer of 1.5-2.0 $\mathrm{m} \mathrm{[34].}$

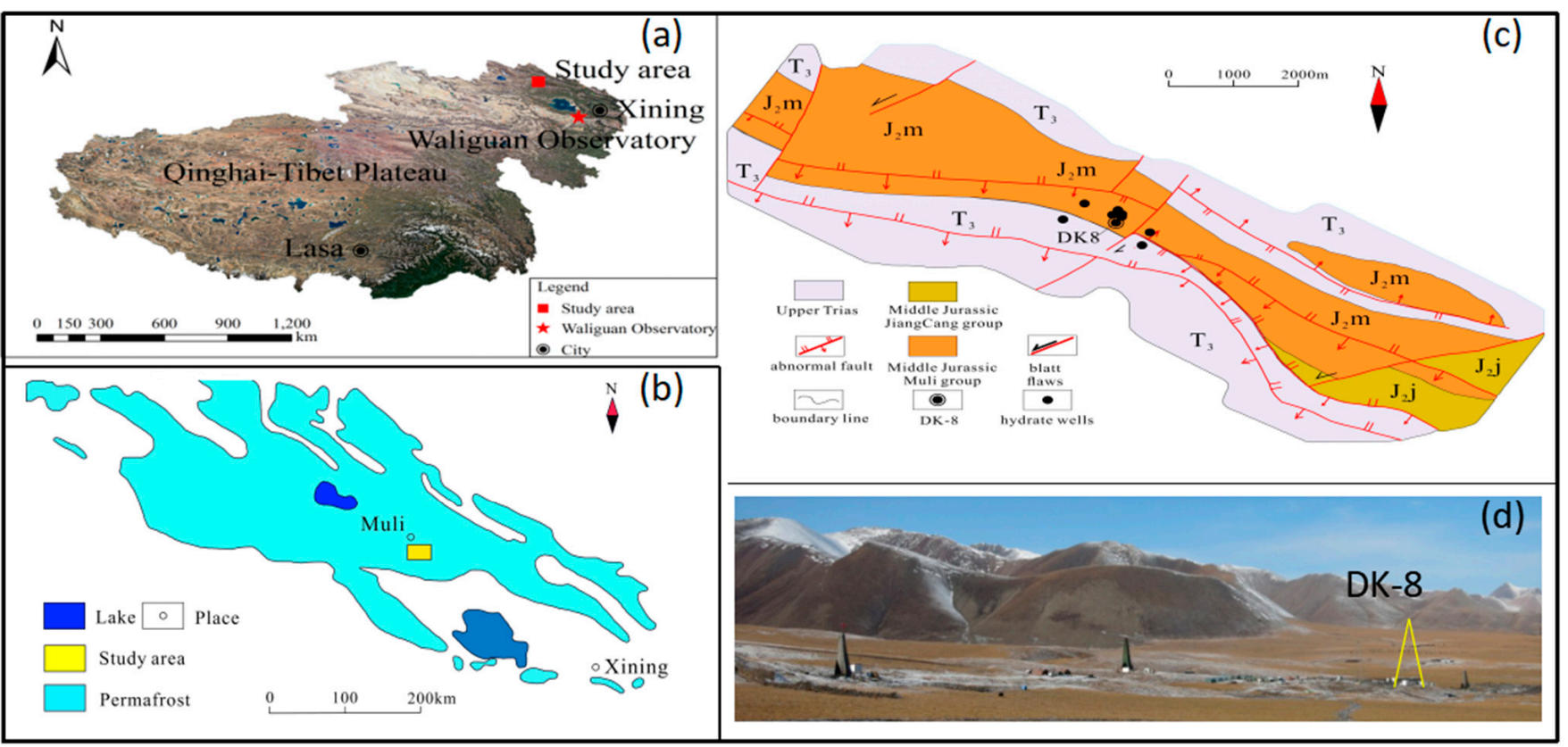

Figure 1. (a) Location of the study area in the Qinghai-Tibet Plateau, (b) permafrost distribution in the Qilian Mountains, (c) geological map showing the faults and the gas hydrate drilling wells, and (d) landscapes near the well DK-8.

The study area is tectonically situated in the western Middle Qilian block formed during the Caledonian Movement (513-386 Ma), adjacent to the South Qilian structural zone [35], and it is also situated in the Muli depression of the south Qilian basin. The exposed strata are Quaternary, Middle Jurassic, and overturned Triassic, which thrust onto the Middle Jurassic. Large NW-SE trending thrust faults developed in the study area (Figure 1c). These thrusts or fractures may serve as paths for gas to migrate upwards from the deep layers, and some of the fractures may serve as temporary gas hydrate-bearing reservoirs [36].

Gas hydrate exploration and scientific drilling work have been performed in permafrost regions in the Qilian Mountains since 2000 [37,38]. A large amount of gas was released when the gas hydrate-bearing cores were extracted under air-tight conditions. Raman spectroscopy identified $\mathrm{CH}_{4}$ as the primary hydrate-forming gas, with secondary components of $\mathrm{C}_{2} \mathrm{H}_{6}, \mathrm{C}_{3} \mathrm{H}_{8}$, and $\mathrm{CO}_{2}$ [14]. The geological and geochemical field exploration work indicated the existence of natural gas hydrate in the target area [36-39]. The gas hydrate is a structure II gas hydrate, mainly stored in siltstone and mudstone of the Middle Jurassic Jiangcang Formation, and secondly, sandstone is unstable and discontinuous in distribution. The occurrence of gas hydrates is closely related to faults, and the burial depth is generally 133-396 $\mathrm{m}$ [40]. 


\subsection{Field Monitoring Method}

The monthly dynamic monitoring of methane in the free gas from the hydrate gas drilling well DK-8 and near-surface soil was conducted simultaneously in situ from January to December in 2017 in the study area. The monitoring frequency is once or twice a month.

The DK-8 well with a diameter of $16.8 \mathrm{~cm}$ was drilled to a depth of approximately $400 \mathrm{~m}$, with the presence of gas hydrate and its associated anomalies mainly within intervals of 150-300 mbs (meter below surface), shown in Figure 2a. The core lithology is mainly composed of sandstone, siltstone, mudstone, and oily shale. The base of the permafrost is around $110 \mathrm{~m}$, revealed by drilling, coexisting with underground ice around $70 \mathrm{mbs}$. The DK-8 was twice tested for exploring gas hydrates in 2011 and 2016, respectively. During the monitoring period, the mouth of the DK-8 was sealed, and the headspace gas can be only derived from the gas emission of the 150-300 mbs layers.

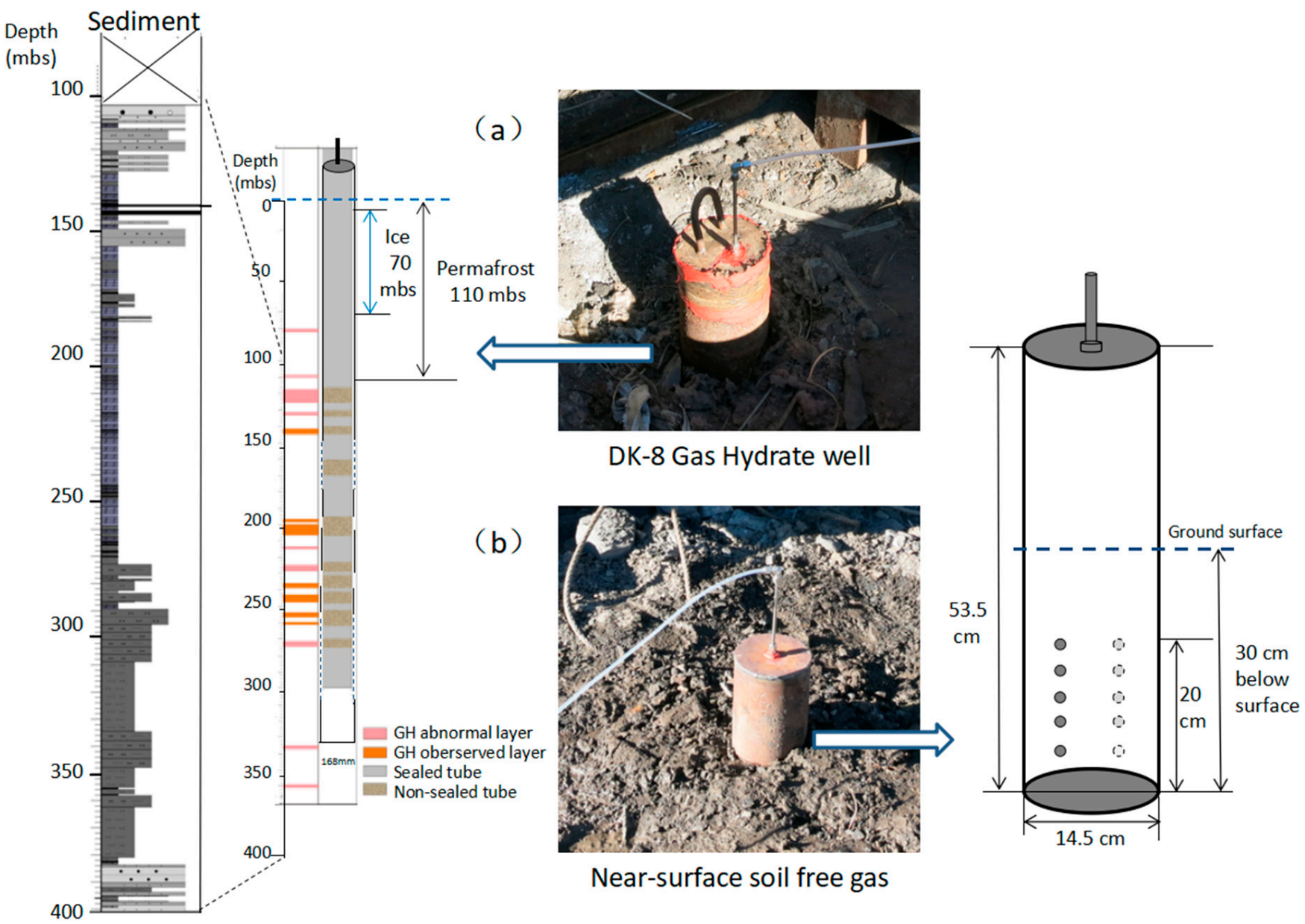

Figure 2. Field monitoring method, (a) gas hydrate drilling well DK-8, (b) near-surface soil-free gas monitored by the designed cylindrical soil respiration chamber.

The free gas from the near-surface soil was monitored using a detachable cylindrical soil respiration chamber that was $14.5 \mathrm{~cm}$ in diameter and $53.5 \mathrm{~cm}$ in height (Figure 2b). The cylindrical chamber was embedded in a pre-excavated hole with a depth of $30 \mathrm{~cm}$ near the well DK-8. After sealing the chamber in the hole, the whole system was circulated with the surrounding soil only through the several sieve holes in the chamber wall $10-30 \mathrm{~cm}$ blew the ground. Disturbance from the mixing of air and soil gas through the soil surface was assumed to be negligible because of the fine texture and compact nature of the soil and gas-tight measurement chamber. 


\subsection{Measurements and Data Processing}

The sampling ports from the well DK-8 and the soil chamber were connected, respectively, to different gas inlets of a portable Picarro isotope analyzer (G2201-i; Cavity Ring-Down Spectroscopy, Picarro, USA). On all sampling occasions, the contents (ppm) and carbon isotope composition $\left(\delta^{13} \mathrm{C}, \%\right.$ vs. $\left.\mathrm{PDB}\right)$ of $\mathrm{CH}_{4}$ together with $\mathrm{CO}_{2}$ were simultaneously measured in situ using the Picarro G2201-i isotope analyzer. The Picarro G2201-i was checked regularly against working standards, and adjustments were made before each field monitoring. The working standards used were a $\mathrm{CH}_{4}$ standard gas of 2 ppm and $10 \mathrm{ppm}$ with the $\delta^{13} \mathrm{C}$ gradients of $0 \%,-20 \%$, $-40 \%$, and $-65 \%$, and used $\mathrm{CO}_{2}$ standard gas of $300 \mathrm{ppm}$ and $600 \mathrm{ppm}$ with the $\delta^{13} \mathrm{C}$ gradient of $0 \%,-10 \%,-20 \%$, and $-30 \%$, respectively. These standard gases were calibrated by the National Institute of Metrology, China.

The readings were collected under a high-accuracy $\mathrm{CH}_{4}-\mathrm{CO}_{2}$ compound mode at intervals of $5 \mathrm{~min}$ for a total duration of at least $4 \mathrm{~h}$ per monitoring. The performance drift of the instrument was checked during the continuous determination for $24 \mathrm{~h}$. The content precision ( $5 \mathrm{~min}, 1 \sigma)$ is $5 \mathrm{ppb}\left(+0.05 \%\right.$ of reading) for $\mathrm{CH}_{4}$ and $200 \mathrm{ppb}(+0.05 \%$ of reading) for $\mathrm{CO}_{2}$, with the guaranteed $\delta^{13} \mathrm{C}$ precision $(5 \mathrm{~min}, 1 \sigma)<1.0 \%$ for $\mathrm{CH}_{4}$ and $<0.2 \%$ for $\mathrm{CO}_{2}$. Moreover, the instrument itself has a temperature control function with an accuracy of $0.5 \%$. The measurement can only be started when the temperature of the instrument chamber reaches $45^{\circ} \mathrm{C}$, thus avoiding the interference of ambient temperature change.

The two gas inlets were alternately switched and measured in succession for each sampling and measurement. To avoid physical fluctuations caused by switching gas inlets, only the measured data during the intermediate 3-min stationary period were taken as valid data to calculate. All valid readings of the total duration per monitoring are calculated as mean \pm standard error and presented as the final result for each measurement. The calculated measurements of $\mathrm{CH}_{4}$ and $\mathrm{CO}_{2}$ content, $\delta^{13} \mathrm{C}_{\mathrm{CH} 4}$ and $\delta^{13} \mathrm{C}_{\mathrm{CO} 2}$, as well as the calculated carbon isotope fractionation $\varepsilon_{C}$ between $\mathrm{CO}_{2}$ and $\mathrm{CH}_{4}\left(\varepsilon_{\mathrm{C}}=\delta^{13} \mathrm{C}_{\mathrm{CO} 2}-\delta^{13} \mathrm{C}_{\mathrm{CH}}\right)$ for the free gas of the DK- 8 hydrate gas drilling well and the active soil layer are shown in Table 1.

Table 1. Methane content and carbon isotopic compositions of methane and carbon dioxide in the gas effused from the DK8 hydrate gas drilling well and in the free gas of the soil active layer.

\begin{tabular}{|c|c|c|c|c|c|}
\hline Sampling Date & $\begin{array}{l}{\left[\mathrm{CH}_{4}\right]} \\
(\mathrm{ppm})\end{array}$ & $\begin{array}{c}\delta^{13} C_{C H 4} \\
(\% \text { vs. PDB) }\end{array}$ & $\begin{array}{l}{\left[\mathrm{CO}_{2}\right]} \\
(\mathrm{ppm})\end{array}$ & $\begin{array}{c}\delta^{13} C_{\mathrm{CO} 2} \\
(\% \text { vs. PDB) }\end{array}$ & $\begin{array}{c}\varepsilon_{\mathrm{C}}\left(=\delta^{13} \mathrm{C}_{\mathrm{CO} 2}-\delta^{13} \mathrm{C}_{\mathrm{CH} 4}\right) \\
(\% \text { vs. PDB })\end{array}$ \\
\hline \multicolumn{6}{|l|}{ DK8 well gas } \\
\hline $2017 / 1 / 6$ & $1.908 \pm 0.018$ & $-48.3 \pm 1.0$ & $413.6 \pm 1.3$ & $-8.8 \pm 0.3$ & 39.5 \\
\hline $2017 / 1 / 15$ & $1.909 \pm 0.001$ & $-47.9 \pm 1.0$ & $415.9 \pm 5.4$ & $-8.9 \pm 0.3$ & 39.1 \\
\hline $2017 / 2 / 4$ & $2.259 \pm 0.058$ & $-45.2 \pm 2.0$ & $331.4 \pm 9.8$ & $-7.5 \pm 0.6$ & 37.7 \\
\hline $2017 / 2 / 17$ & $1.904 \pm 0.001$ & $-46.9 \pm 1.0$ & $435.8 \pm 26.5$ & $-7.5 \pm 1.0$ & 39.3 \\
\hline $2017 / 3 / 6$ & $1.944 \pm 0.006$ & $-47.2 \pm 0.9$ & $463.6 \pm 8.3$ & $-9.5 \pm 0.5$ & 37.7 \\
\hline $2017 / 3 / 16$ & $1.921 \pm 0.005$ & $-47.0 \pm 0.9$ & $434.2 \pm 14.6$ & $-8.2 \pm 0.7$ & 38.8 \\
\hline $2017 / 3 / 26$ & $1.923 \pm 0.004$ & $-45.5 \pm 1.1$ & $462.7 \pm 6.9$ & $-6.6 \pm 1.2$ & 38.8 \\
\hline $2017 / 4 / 6$ & $2.920 \pm 0.148$ & $-39.9 \pm 1.4$ & $337.9 \pm 10.0$ & $-7.7 \pm 0.6$ & 32.1 \\
\hline $2017 / 4 / 19$ & $1.983 \pm 0.007$ & $-44.9 \pm 1.0$ & $455.1 \pm 14.0$ & $-6.5 \pm 1.0$ & 38.4 \\
\hline $2017 / 5 / 9$ & $8.530 \pm 1.983$ & $-31.5 \pm 0.8$ & $302.6 \pm 22.2$ & $-6.2 \pm 0.9$ & 25.3 \\
\hline $2017 / 5 / 23$ & $4.201 \pm 0.078$ & $-34.6 \pm 1.1$ & $325.9 \pm 1.5$ & $-5.4 \pm 1.2$ & 29.2 \\
\hline $2017 / 6 / 15$ & $1.920 \pm 0.022$ & $-49.0 \pm 1.3$ & $405.6 \pm 0.8$ & $-4.6 \pm 1.2$ & 44.4 \\
\hline $2017 / 7 / 17$ & $1.993 \pm 0.007$ & $-49.6 \pm 1.3$ & $429.6 \pm 2.4$ & $-3.3 \pm 0.3$ & 46.3 \\
\hline $2017 / 8 / 26$ & $2.132 \pm 0.069$ & $-46.2 \pm 1.6$ & $395.0 \pm 5.5$ & $-6.9 \pm 0.9$ & 39.3 \\
\hline
\end{tabular}


Table 1. Cont.

\begin{tabular}{|c|c|c|c|c|c|}
\hline Sampling Date & $\begin{array}{l}{\left[\mathrm{CH}_{4}\right]} \\
(\mathrm{ppm})\end{array}$ & $\begin{array}{c}\delta^{13} \mathrm{C}_{\mathrm{CH} 4} \\
\text { (\%o vs. PDB) }\end{array}$ & $\begin{array}{l}{\left[\mathrm{CO}_{2}\right]} \\
(\mathrm{ppm})\end{array}$ & $\begin{array}{c}\delta^{13} \mathrm{C}_{\mathrm{CO} 2} \\
\text { (\%o vs. PDB) }\end{array}$ & $\begin{array}{c}\varepsilon_{\mathrm{C}}\left(=\delta^{13} \mathrm{C}_{\mathrm{CO} 2}-\delta^{13} \mathrm{C}_{\mathrm{CH} 4}\right) \\
(\% \text { vs. PDB })\end{array}$ \\
\hline \multicolumn{6}{|c|}{ Free gas of the active soil layer (10-30 cm depth) } \\
\hline $2017 / 1 / 15$ & $1.992 \pm 0.086$ & $-49.4 \pm 1.6$ & $437.9 \pm 6.0$ & $-9.9 \pm 0.4$ & 39.5 \\
\hline $2017 / 2 / 4$ & $1.920 \pm 0.045$ & $-48.8 \pm 1.2$ & $471.3 \pm 36.0$ & $-9.7 \pm 2.8$ & 39.2 \\
\hline $2017 / 2 / 17$ & $1.906 \pm 0.003$ & $-47.3 \pm 1.2$ & $435.4 \pm 23.6$ & $-7.4 \pm 0.9$ & 40.0 \\
\hline $2017 / 3 / 6$ & $1.951 \pm 0.006$ & $-50.5 \pm 1.4$ & $464.2 \pm 8.0$ & $-9.3 \pm 0.4$ & 41.3 \\
\hline $2017 / 3 / 16$ & $1.926 \pm 0.005$ & $-50.8 \pm 1.6$ & $436.3 \pm 14.5$ & $-8.1 \pm 0.6$ & 42.7 \\
\hline $2017 / 3 / 26$ & $1.924 \pm 0.069$ & $-48.9 \pm 2.1$ & $466.9 \pm 8.2$ & $-6.3 \pm 1.3$ & 42.6 \\
\hline $2017 / 4 / 6$ & $2.390 \pm 0.303$ & $-43.2 \pm 1.8$ & $474.6 \pm 21.9$ & $-9.3 \pm 0.7$ & 33.9 \\
\hline $2017 / 4 / 19$ & $1.962 \pm 0.016$ & $-48.7 \pm 1.3$ & $445.8 \pm 23.0$ & $-9.3 \pm 0.4$ & 39.4 \\
\hline $2017 / 5 / 9$ & $1.964 \pm 0.077$ & $-49.9 \pm 1.0$ & $426.5 \pm 14.0$ & $-7.5 \pm 0.8$ & 42.4 \\
\hline $2017 / 5 / 23$ & $1.976 \pm 0.110$ & $-49.4 \pm 2.0$ & $407.6 \pm 1.8$ & $-7.8 \pm 0.9$ & 41.5 \\
\hline $2017 / 6 / 15$ & $1.929 \pm 0.012$ & $-51.3 \pm 1.4$ & $438.4 \pm 12.0$ & $-8.1 \pm 0.9$ & 43.2 \\
\hline $2017 / 7 / 17$ & $1.988 \pm 0.005$ & $-52.0 \pm 1.2$ & $503.5 \pm 4.1$ & $-4.1 \pm 0.3$ & 47.9 \\
\hline $2017 / 8 / 26$ & $2.027 \pm 0.047$ & $-50.7 \pm 1.5$ & $441.8 \pm 28.6$ & $-4.8 \pm 0.8$ & 46.0 \\
\hline $2017 / 10 / 18$ & $1.920 \pm 0.017$ & $-47.9 \pm 1.5$ & $425.3 \pm 20.7$ & $-10.5 \pm 1.5$ & 37.4 \\
\hline $2017 / 12 / 2$ & $1.909 \pm 0.001$ & $-45.2 \pm 1.2$ & $778.7 \pm 49.8$ & $-13.4 \pm 1.0$ & 31.9 \\
\hline $2017 / 12 / 12$ & $1.907 \pm 0.004$ & $-44.0 \pm 1.3$ & $663.2 \pm 12.4$ & $-14.2 \pm 1.3$ & 29.8 \\
\hline $2017 / 12 / 28$ & $1.947 \pm 0.018$ & $-44.5 \pm 1.9$ & $576.4 \pm 10.5$ & $-15.9 \pm 2.1$ & 28.6 \\
\hline
\end{tabular}

\section{Results}

\subsection{Monthly Temperature Variation of the Soil upper Active Layer}

The monthly temperature variation of the soil's upper active layer, as well as the low-level air, at the gas hydrate drilling area in the Muli permafrost is shown in Figure 3, based on the average daily monitoring data in 2017 . The soil temperature varied with the atmospheric temperature in a range of $-16-16^{\circ} \mathrm{C}$, lower than that of the atmospheric temperature $\left(-25-18^{\circ} \mathrm{C}\right)$. The soil temperature was observed above $0{ }^{\circ} \mathrm{C}$ first in early April and was always greater than $0{ }^{\circ} \mathrm{C}$ between May and October, which is the main period of permafrost thawing. The frozen period characterized by the soil temperature lower than $0{ }^{\circ} \mathrm{C}$ was from November to next April.

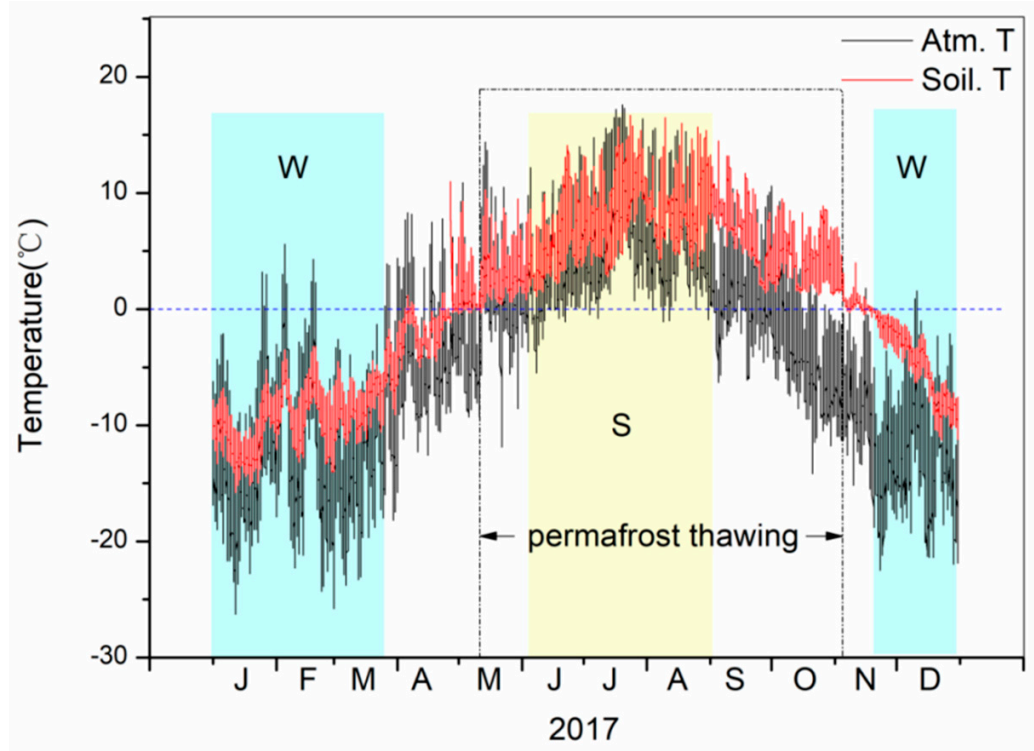

Figure 3. Daily temperature curves of low-level air and soil active layer in the Muli permafrost of the Qilian Mountains from January to December in 2017. 


\subsection{Methane Content and Carbon Isotopic Compositions Derived from the Drilling Well DK-8}

The monthly variation in content and carbon isotopic composition of methane derived from the hydrate drilling well DK-8 during the period from January to August in 2017 is shown in Figure 4. The measured methane contents showed a large variation from $1.904 \pm 0.001$ to $8.530 \pm 1.983$ ppm. The methane was constant at a low concentration of $1.967 \pm 0.130$ ppm from January to March and of $2.015 \pm 0.108$ ppm from June to August, whereas it significantly increased to $2.920 \mathrm{ppm}$ in early April and soared to $8.530 \mathrm{ppm}$ in early May and $4.201 \mathrm{ppm}$ in late May. The measured $\delta^{13} \mathrm{C}_{\mathrm{CH}}$ values varied between $-49.6 \%$ and $-34.6 \%$, parallel with methane contents (Figure 4 ). Overall, the higher $\mathrm{CH}_{4}$ content had less negative $\delta^{13} \mathrm{C}_{\mathrm{CH} 4}$, while lower $\mathrm{CH}_{4}$ content had more negative $\delta^{13} \mathrm{C}_{\mathrm{CH}}$. Specifically, for the higher content of $\mathrm{CH}_{4}$, the $\delta^{13} \mathrm{C}_{\mathrm{CH} 4}$ values were $-39.9 \%$ in early April, $-31.5 \%$ in early May, and $-34.6 \%$ in late May, compared with $-47.1 \pm 1.5 \%$ for the steady low content of $\mathrm{CH}_{4}$. The carbon isotope fractionation $\left(\varepsilon_{\mathrm{C}}\right)$ between $\mathrm{CO}_{2}$ and $\mathrm{CH}_{4}$ varied between $25.3 \%$ and $46.3 \%$, with the highest in July and the lowest in May. The $\varepsilon_{C}$ values are negatively correlated with the $\delta^{13} C_{\mathrm{CH} 4}$ values with a Pearson's r of -0.94997 .

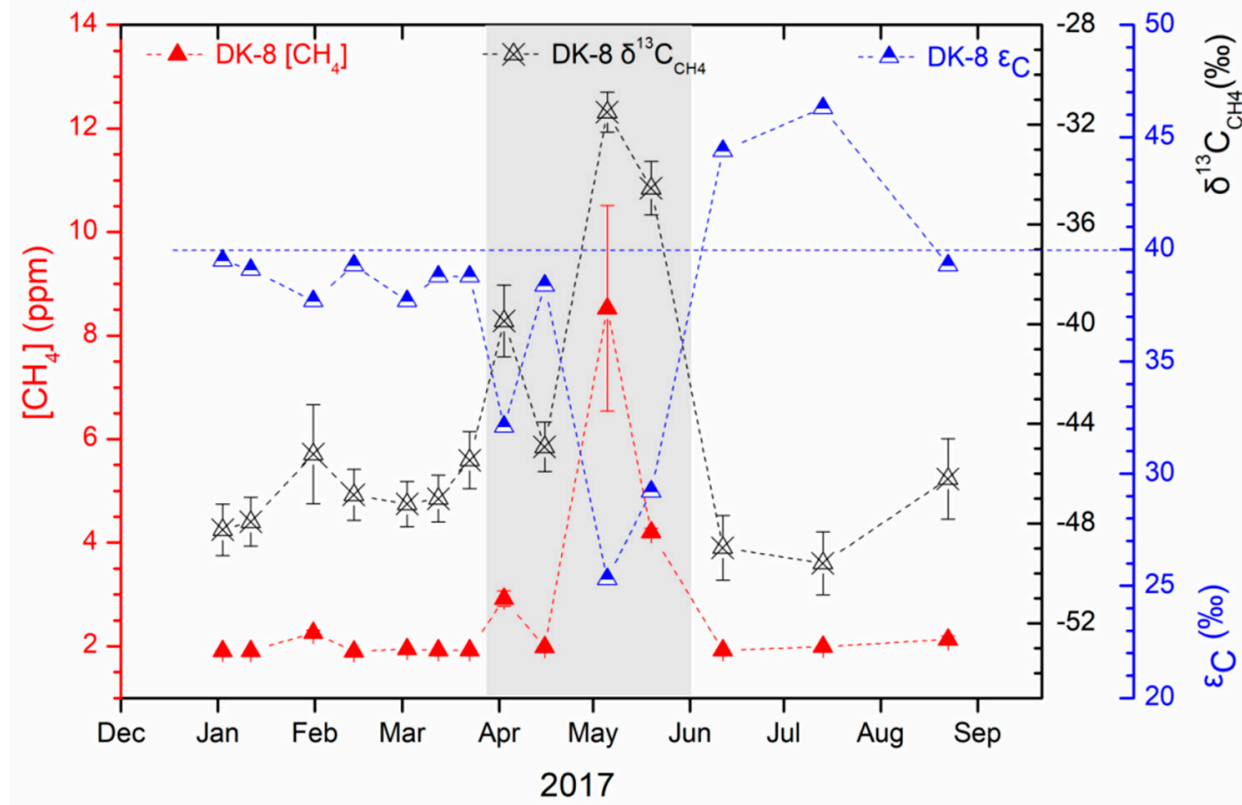

Figure 4. Content and stable carbon isotopic composition $\left(\delta^{13} \mathrm{C}_{\mathrm{CH} 4}\right)$ of methane and carbon isotope separation $\left(\varepsilon_{\mathrm{C}}\right)$ between $\mathrm{CH}_{4}$ and $\mathrm{CO}_{2}$ effused from the gas hydrate drilling well DK-8.

3.3. Methane Content and Carbon Isotopic Compositions of Free Gas from the Upper of Soil Active Layer

The $\mathrm{CH}_{4}$ content of the soil chamber varied from $1.906 \pm 0.003$ to $2.390 \pm 0.303$ ppm in 2017 , with an average of $1.973 \pm 0.113 \mathrm{ppm}$. Their $\delta^{13} \mathrm{C}_{\mathrm{CH} 4}$ values, representing that of the upper soil active layer, ranged between $-52.0 \pm 1.2 \%$ ond $-43.2 \pm 1.8 \%$ with an average of $-48.4 \pm 2.7 \%$. The $\delta^{13} \mathrm{C}_{\mathrm{CH} 4}$ values measured in March-August $(-50.2 \pm 1.1 \%$ o $)$ were lower than those measured in October-February $\left(-46.7 \pm 2.1 \%\right.$ o). Particularly, the $\mathrm{CH}_{4}$ with soaring content $(2.390 \pm 0.303 \mathrm{ppm})$ in early April had significantly higher $\delta^{13} \mathrm{C}_{\mathrm{CH} 4}$ values $(-43.2 \pm 1.8 \%$ o $)$ than that in other months (Figure 5$)$, suggesting a significant increase of the methane source that has more positive $\delta^{13} \mathrm{C}_{\mathrm{CH}}$. The carbon isotope fractionation $\left(\varepsilon_{\mathrm{C}}\right)$ between $\mathrm{CO}_{2}$ and $\mathrm{CH}_{4}$ ranged between $28.6 \%$ and $47.9 \%$, with the highest in July and the lowest in December. The significant increasing and decreasing trend of the $\varepsilon_{C}$ values were observed in the periods from April to July and from July to December, respectively. The $\varepsilon_{C}$ values were negatively correlated with the $\delta^{13} \mathrm{C}_{\mathrm{CH} 4}$ values with a Pearson's $\mathrm{r}$ of -0.9115 . 


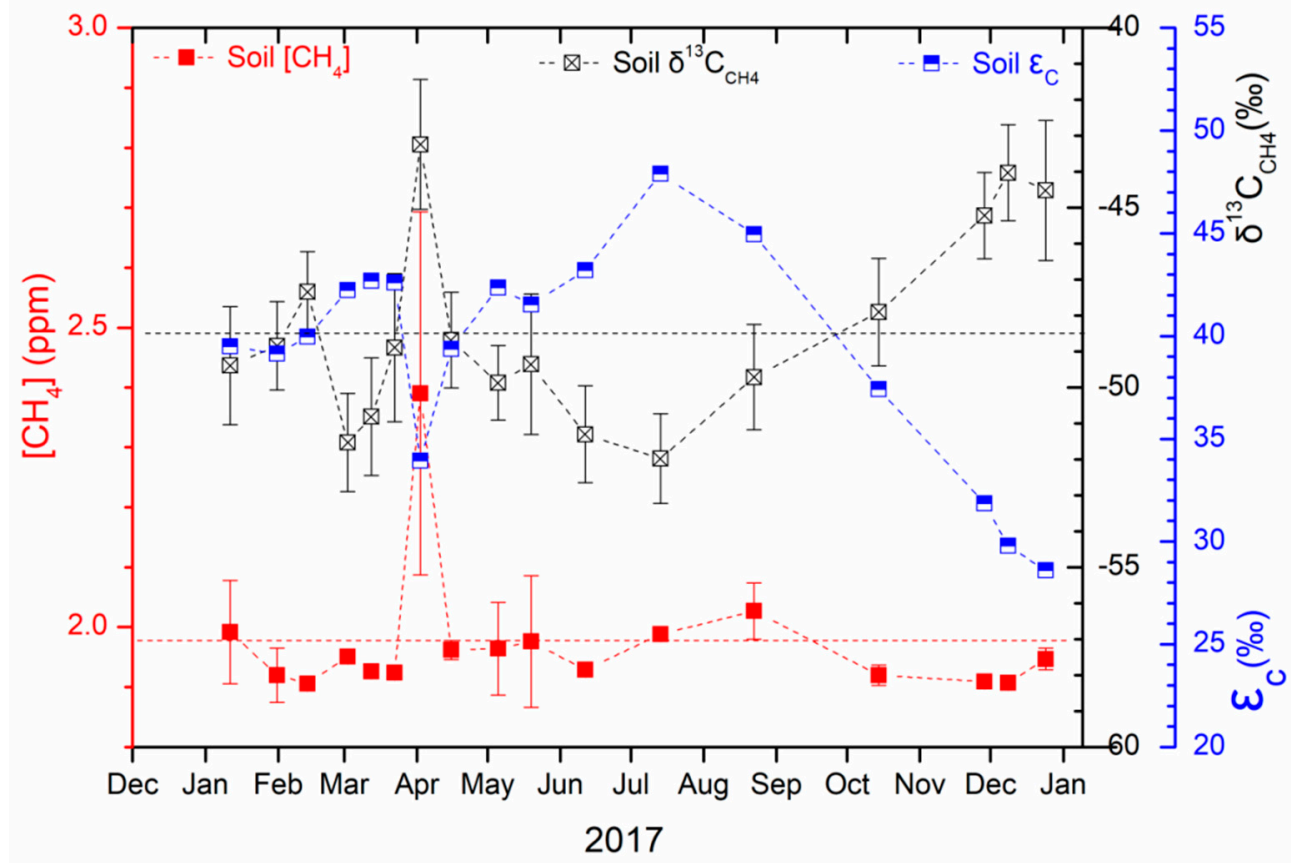

Figure 5. Content and stable carbon isotopic composition of methane $\left(\delta^{13} \mathrm{C}_{\mathrm{CH}}\right)$ and carbon isotope fractionation $\left(\varepsilon_{\mathrm{C}}\right)$ between $\mathrm{CO}_{2}$ and $\mathrm{CH}_{4}$ in the free gas of the soil active layer.

\section{Discussion}

\subsection{Carbon Isotopic Signatures for Methane Derived from Gas Hydrate Dissociation}

We used Keeling and Miller Tans plots [41-43] to explore the potential source isotopic signature of fresh $\mathrm{CH}_{4}$ and $\mathrm{CO}_{2}$ escaping from the drilling well DK-8. The source isotopic signature for $\mathrm{CH}_{4}\left(\delta_{\mathrm{S}}\right)$ was calculated as the intercept value $(-25.9 \pm 1.4 \%$ o of the regression associated with the Keeling plot (Figure $6 \mathrm{a})$ and as the slop value $(-26.5 \pm 0.5 \%$ o of the regression associated with the Miller Tans plot (Figure $6 \mathrm{~b}$ ), respectively. There was no clear distinction in identified $\delta_{\mathrm{s}}$ values between the two methods. The less negative $\delta^{13} \mathrm{C}_{\mathrm{CH} 4}$ values are typical of thermogenically-derived methane sources enriched in ${ }^{13} \mathrm{C}$ ( $-50 \%$ to $-20 \%$, [32]). The isotopic signature of the $\mathrm{CH}_{4}$ source for the well DK-8 is also consistent with $\delta^{13} \mathrm{C}_{\mathrm{CH} 4}$ values $(-17.7 \%$ to $-34.7 \%$ ) of headspace gases from gashydrate-bearing DK-8 drill cores at depths of 184-291 m [36]. Gases from the gas hydrate samples in the Muli permafrost were mainly thermogenic, either of coal-derived or oilderived origin, discerned by the combined plots of $\delta^{13} C_{1}-C_{1} /\left(C_{2}+C_{3}\right)[30,40,44-46], \delta^{13} C_{1}$ $\delta^{13} C_{2}-\delta^{13} C_{3}[47,48]$, and $\delta^{13} C_{1}-\delta D_{1}[44]$. However, the Pearson's correlation coefficients between $\delta^{13} \mathrm{C}_{\mathrm{CO} 2}$ and $1 /\left[\mathrm{CO}_{2}\right]$ and between $\delta^{13} \mathrm{C}_{\mathrm{CO}_{2}}{ }^{*}\left[\mathrm{CO}_{2}\right]$ and $\mathrm{CO}_{2}$ content were low $(\mathrm{r}=0.1768$ and $\mathrm{r}=-0.5690, p>0.05$, respectively). Thus, the traditional "Keeling plot" or "Miller Tans plots" two end-member mixing model cannot estimate the fresh $\mathrm{CO}_{2}$ source. The $\mathrm{CO}_{2}$ contents $(422.0 \pm 37.7 \mathrm{ppm})$ were considerably greater than the $\mathrm{CH}_{4}$ contents (1.98 $\pm 0.11 \mathrm{ppm})$, suggesting the importance of some other mechanisms of $\mathrm{CO}_{2}$ production. Therefore, besides the hydrate-forming gas, the $\mathrm{CO}_{2}$ source is not specified in this study, which may come from the deep depth or from soil organic decomposition.

The increasing $\mathrm{CH}_{4}$ content of well DK-8 in April-May was observed with less negative $\delta^{13} \mathrm{C}_{\mathrm{CH} 4}$ values than $-40 \%$ (Figure 4 ), indicating a substantial proportion of releasing $\mathrm{CH}_{4}$ from gas hydrate dissociation. The $\mathrm{CH}_{4}$ from gas hydrate dissociation in the permafrost layer at a depth of 150-305 m can diffuse into well DK-8 and be trapped and accumulated in the ice of the well during upward diffusion when the soil temperature is lower than $0{ }^{\circ} \mathrm{C}$. The occurring of a considerable increase of $\mathrm{CH}_{4}$ content of the well DK-8 coincides with the initial melting of the ice of the well in early April when the soil temperature first raises above $0{ }^{\circ} \mathrm{C}$. The peak of the $\mathrm{CH}_{4}$ content also coincides with the complete melting process in early May when the soil temperature is always above $0{ }^{\circ} \mathrm{C}$. 

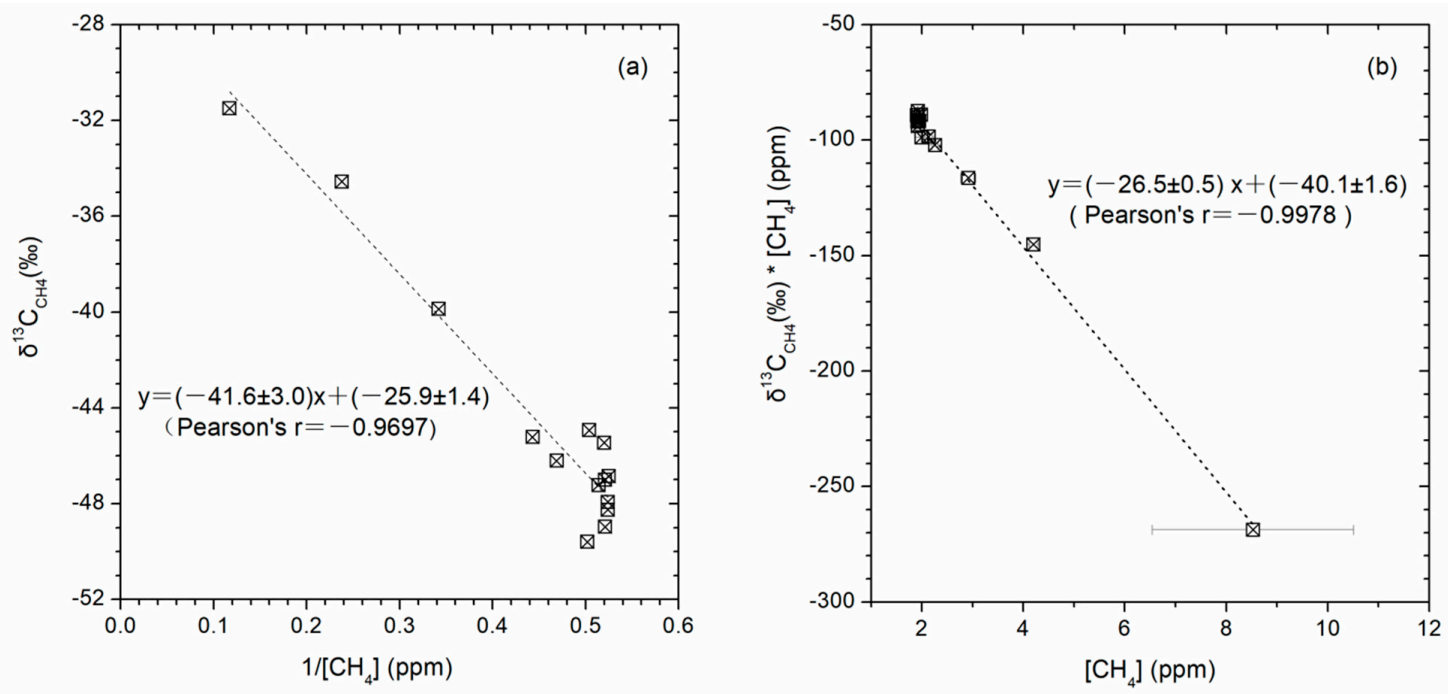

Figure 6. Qualitative assessment of source $\mathrm{CH}_{4}$ isotopic composition. (a) Keeling plot showing the relationship between $\delta^{13} \mathrm{C}_{\mathrm{CH} 4}$ and the inverse of $\mathrm{CH}_{4}$ content with the intercept of the regression as $\delta$ s. (b) Miller-Tans plot showing the relationship between $\delta^{13} \mathrm{C}_{\mathrm{CH} 4 \mathrm{c}}{ }^{*}\left[\mathrm{CH}_{4}\right]$ content and the slope of the regression as $\delta \mathrm{s}$.

The carbon isotope fractionation $\left(\varepsilon_{\mathrm{C}}\right)$ between $\mathrm{CO}_{2}$ and $\mathrm{CH}_{4}$ can be indicative of the particular methanogenic pathway [32]. The $\varepsilon_{C}$ values of gas hydrates in the Muli permafrost are calculated based on the reported $\delta^{13} \mathrm{C}$ data of gas components $\left(\mathrm{CH}_{4}\right.$ and $\left.\mathrm{CO}_{2}\right)$ of the drilled gas hydrate samples summarized by Dai et al. [48]. The $\varepsilon_{C}$ values are characterized by $21.5-35.8 \%$, with an average of $29.8 \%$ (Figure 7 ), associated with the average $\delta^{13} \mathrm{C}_{\mathrm{CH}}$ and $\delta^{13} \mathrm{C}_{\mathrm{CO} 2}$ of $-45.3 \pm 5.8 \%$ and $-13.2 \pm 7.3 \%$. The calculated $\varepsilon_{\mathrm{C}}$ values of gases from well DK-8 that correspond to more $\mathrm{CH}_{4}$ content and higher $\delta^{13} \mathrm{C}_{\mathrm{CH}}$ were $25.3-32.1 \%$, which is consistent with the thermogenic gas hydrate dissociation. This consistency shows no to little carbon isotopic fractionation during upward transport through the drilling wells. Moreover, the $\varepsilon_{C}$ values of gas hydrates are distinctly lower than those associated with microbial methanogenesis predominantly by carbonate reduction $\left(\varepsilon_{C}\right.$ from $49 \%$ o to over $100 \%$, [32] ) or by fermentation of methylated substrates ( $\varepsilon_{C}$ typically between $40 \%$ and $55 \%$, [32]) and distinctly higher than those associated with microbial methane oxidation ( $\varepsilon_{C}$ generally less than $10 \%$, [32]). Therefore, the $\varepsilon_{C}$ of $20-36 \%$ can be a carbon isotopic signature of thermogenic gas hydrate. The lower $\varepsilon_{C}$ values associated with the $\delta^{13} \mathrm{C}_{\mathrm{CH}}$ higher than $-40 \%$ further suggest considerable contribution from gas hydrate in April-May. The higher $\varepsilon_{\mathrm{C}}$ values $\left(44.4-46.3 \%\right.$ o) associated with lower $\delta^{13} \mathrm{C}_{\mathrm{CH}}(\sim-49 \%$ o $)$ indicate an increasing contribution of a microbial source in June-July due to the elevated temperatures.

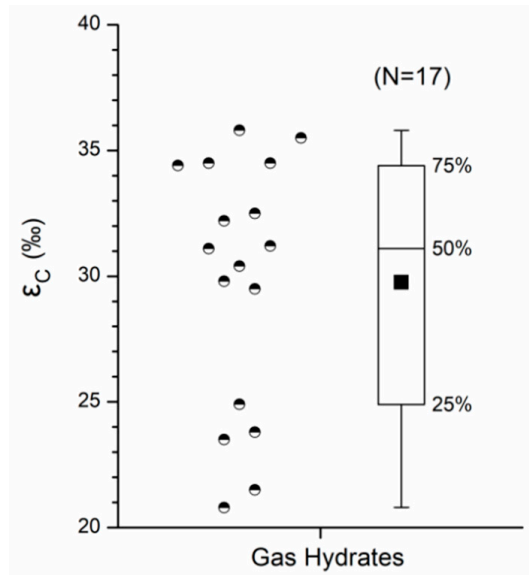

Figure 7. The boxplot of the calculated $\varepsilon_{C}$ values of gas hydrates in the Muli permafrost. 


\subsection{Sources of Seasonal Wetland Methane Emission Affected by Gas Hydrate Drilling}

The flux and area-weighted mean global source signature from wetlands is - $62 \%$ [49], which is similar to the mean microbial signature of $61.5 \pm 0.6 \%$ [50]. The source signature map resolves a latitudinal difference of $\sim 10 \%$ between northern high-latitude (mean $67.8 \%$ ) and tropical (mean $56.7 \%$ ) wetlands [49]. However, the annual average of $\delta^{13} \mathrm{C}_{\mathrm{CH} 4}$ in the study area is $-48.4 \pm 2.7 \%$, significantly more enriched than the global source isotopic signature. The soil-emitted $\delta^{13} \mathrm{C}_{\mathrm{CH} 4}$ in summer $(-51.3 \pm 0.9 \%$ o of the study area is similar to that in two bogs $(-53.0 \pm 5.5 \%$ and $-55.3 \pm 5.5 \%$ o separated by $>1000 \mathrm{~km}$ over the Qinghai-Tibetan Plateau [51], but distinctly different from that of the northern European wetlands $\left(-71 \pm 1 \%\right.$ ) [52]. In particular, more enriched $8^{13} \mathrm{C}_{\mathrm{CH} 4}$ of the soilemitted methane was observed in December than in July-August, reflecting highly variable seasonal wetland methane sources. Compared with wetlands away from gas hydrate in the Qinghai-Tibetan Plateau, there was no significant difference of soil-emitted $\delta^{13} \mathrm{C}_{\mathrm{CH} 4}$ between summer (from $-60.6 \%$ to $-54.6 \%$ ) and winter ( $-65.5 \%$ o to $-55.8 \%$ ) [53].

The gases of thermogenic gas hydrates samples in the Muli permafrost of the Qilian Mountains had distinctive $\delta^{13} \mathrm{C}_{\mathrm{CH} 4}$ values heavier than $-50 \%$ and $\varepsilon_{\mathrm{C}}$ values lower at $20-36 \%$ from the microbially-derived methane with $\delta^{13} \mathrm{C}_{\mathrm{CH}}$ lighter than $-50 \%$ and $\varepsilon_{\mathrm{C}}$ values more than $40 \%$. Therefore, the isotope signatures of $\delta^{13} \mathrm{C}_{\mathrm{CH} 4}$ combined with $\varepsilon_{\mathrm{C}}$ can be adequate to reliably distinguish microbially or thermogenically derived methane. The two dominated microbial and thermogenic sources controlling seasonal variation of the wetland methane emission in the study area are indicated by linear correlation of binary mixing in the diagram of $\varepsilon_{\mathrm{C}}$ versus $\delta^{13} \mathrm{C}_{\mathrm{CH} 4}$ (Figure 8). The samples collected in spring and summer plotted in the microbial zone indicated the soil-emitted $\mathrm{CH}_{4}$ being dominated by fermentation of methylated substrates $\left(\delta^{13} \mathrm{C}_{\mathrm{CH} 4}=-50 \%\right.$ to $-60 \%$, $\varepsilon_{\mathrm{C}}=40-60 \%$, [32]). Further, the samples in autumn and winter are plotted beyond the microbial zone and along the fitting line into the thermogenic zone, indicating an increasing contribution of thermogenic gas hydrates. A response of soil methane emission to the $\mathrm{CH}_{4}$ effusion peak out of well DK-8 occurred on April 6 and can be observed by the $\mathrm{CH}_{4}$ surge $(2390 \mathrm{ppm})$, less negative $\delta^{13} \mathrm{C}_{\mathrm{CH} 4}(-43.2 \%$ ), and lower $\varepsilon_{\mathrm{C}}(33.9 \%)$ during the same period. The soil-emitted $\mathrm{CH}_{4}$ on April 6 plotted in the thermogenic zone (Figure 8 ) suggests the accumulated thermogenic gas hydrate dissociation in the ice of drilling wells is an important source of soil-emitted methane.

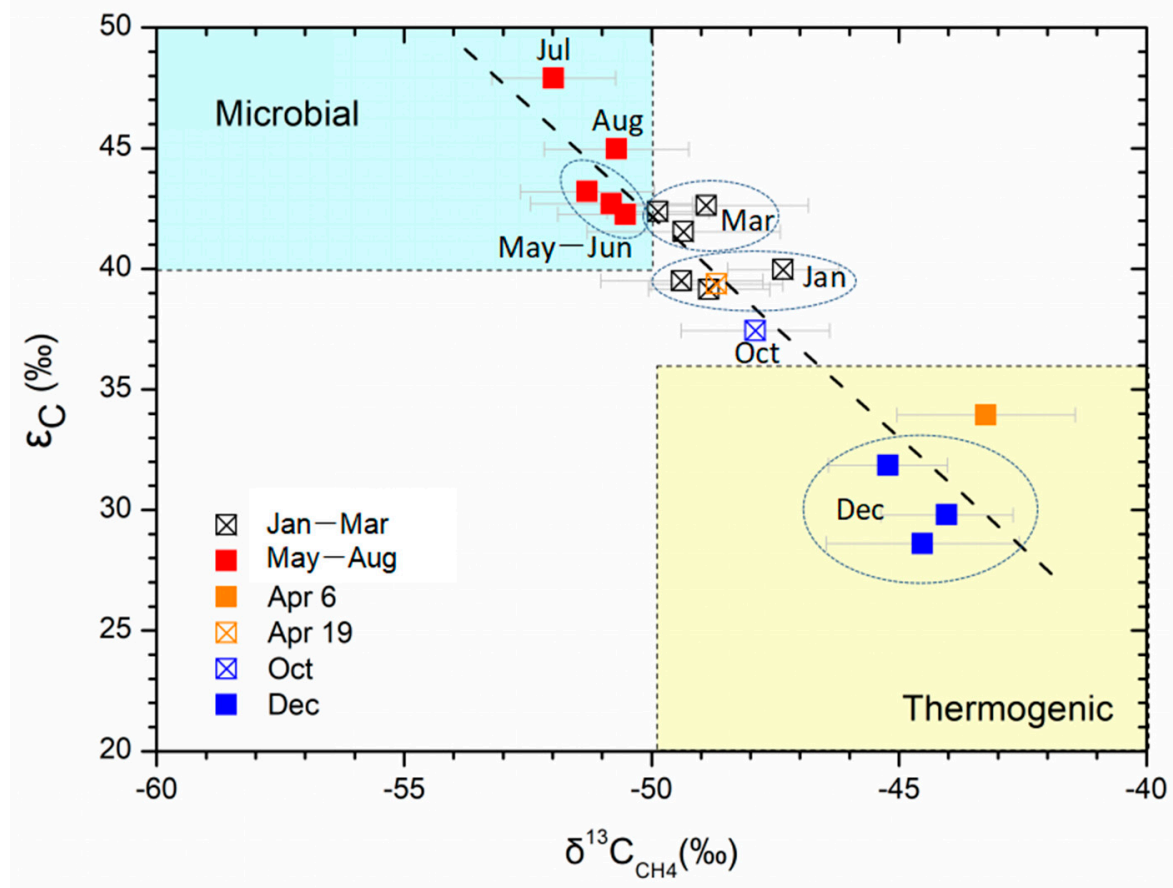

Figure 8. Carbon isotopic composition of wetland methane emission showing the seasonal variation of soil-emitted methane source derived from microbial and thermogenic origins. 
The combined effects of both microbially and thermogenically derived methane control the seasonal variation of wetland methane emission. This finding further suggests gas hydrate dissociation affected by drilling activities is an important source of methane emission from wetlands in the Muli permafrost. During spring and summer, microbes are the dominant source of soil-emitted methane, although the thermogenic methane emission from subterranean gas hydrates can be accelerated through new channels resulting from permafrost thawing. The increase in temperature accompanied by permafrost thawing promoted an exponential boost in the scale of microbial communities and activity [54-56] during the transition from spring to summer, which results in increasing methane produced by methanogenic microbes from May to July. However, with an increase in temperature to a certain extent, the upper limit of the environmental carrying capacity of methanogenic microbial communities is reached [57], which leads to a lower contribution of microbial methane in August than in July.

During the transition from late summer to autumn, microbial activities become weaker as the temperature decreases and the consequential reduction in methane production by methanogens. As a result, the methane contribution from the microbial source decreased, and that from the thermogenic source relatively increased in October. During winter, significant decreases occur on the scale of microbial communities and microbial activity [58], especially at temperatures below $-10^{\circ} \mathrm{C}$. This leads to a substantial reduction in the amount of methane produced by methanogens. Thus, the contribution of the thermogenically derived methane relatively increased. The carbon isotope compositions of $\delta^{13} \mathrm{C}_{\mathrm{CH} 4}$ and $\varepsilon_{\mathrm{C}}$ of wetland emission consistently reflected the dynamic variation of relative contributions of microbial and thermogenic methane during autumn and winter. In addition, as the average daily temperature falls below zero, freezing occurs in the permafrost, which leads to the decreased effusion of methane from subterranean gas hydrates. The dominance of thermogenically derived methane in December is shown in Figure 8, suggesting that the subterranean gas hydrates dissociation may seep through faults or drainage systems or drilled-through permafrost layers upward into the wetland.

\section{Conclusions}

The twelve-month systematic field monitoring of methane sources at a typical gas hydrate drilling site in the Muli permafrost of the Qilian Mountains provided carbon isotopic evidence that thermogenic gas hydrate dissociation is an important source of wetland methane emission affected by drilling activities. The combined application of carbon isotope fractionation $\left(\varepsilon_{\mathrm{C}}\right)$ between $\mathrm{CH}_{4}$ and $\mathrm{CO}_{2}$ and carbon isotopic composition of methane $\left(\delta^{13} \mathrm{C}_{\mathrm{CH} 4}\right)$ to distinguish thermogenic from microbial methane is well established and appears to be useful in complex environments. The carbon isotopic signatures for methane derived from gas hydrate dissociation determined by the gas hydrate drilling DK-8 is distinctly characterized by heavier $\delta^{13} \mathrm{C}_{\mathrm{CH} 4}$ of $-26.5 \pm 0.5 \%$ and lower $\varepsilon_{\mathrm{C}}$ of $-25.3 \%$ o to $-32.1 \%$. The seasonal variation of methane sources of near-surface soil fluxes at the drilling site confirmed the significance of methane emission from the thermogenic gas hydrates on local permafrost wetland methane emission, especially in autumn and winter. The effect of gas hydrate dissociation on methane emission of the permafrost wetland may become more significant with the further exploration of gas hydrate resources. The effect of gas hydrate on regional wetland methane emission in the Muli permafrost requires more research to fully understand, which will allow for exploration of the mechanisms of soil methane emissions in the permafrost wetlands of the Qinghai-Tibet Plateau as the global climate warms.

Author Contributions: X.L., interpreted the data and wrote the paper and acquired funding; S.P., conceived and designed the research; J.X. performed data analysis and figure drawing; Y.Z., performed fieldwork supervision and funding acquisition; S.Z., R.X., and C.L. performed field investigation and monitoring. All authors have read and agreed to the published version of the manuscript. 
Funding: This study was financially supported by the open fund project of the Key Laboratory of Unconventional Oil \& Gas Geology, China Geological Survey (CGS) (No. DD2019137-YQ19JJ02), and the National geological survey project of China (No. DD20190102).

Institutional Review Board Statement: This article does not contain studies with human participant or animals performed by any of the authors.

Informed Consent Statement: Not applicable.

Data Availability Statement: The data generated or analyzed during this study were included in this manuscript.

Acknowledgments: We are grateful to the Muli Field Scientific Observation and Research Station for Gas Hydrate, CGS, for the convenience and help during field work.

Conflicts of Interest: The authors declare no conflict of interest.

\section{References}

1. Shindell, D.T.; Faluvegi, G.; Koch, D.M.; Schmidt, G.A.; Unger, N.; Bauer, S.E. Improved Attribution of Climate Forcing to Emissions. Science 2009, 326, 716-718. [CrossRef] [PubMed]

2. Dalsøren, S.B.; Myhre, C.L.; Myhre, G.; Gomez-Pelaez, A.J.; Søvde, O.A.; Isaksen, I.S.A.; Weiss, R.F.; Harth, C.M. Atmospheric methane evolution the last 40 years. Atmospheric Chem. Phys. 2016, 16, 3099-3126. [CrossRef]

3. Zhang, Z.; Zimmermann, N.E.; Stenke, A.; Li, X.; Hodson, E.L.; Zhu, G.; Huang, C.; Poulter, B. Emerging role of wetland methane emissions in driving 21st century climate change. Proc. Natl. Acad. Sci. USA 2017, 114, 9647-9652. [CrossRef] [PubMed]

4. Zimov, S.A.; Schuur, E.A.G.; Chapin, F.S. Permafrost and the Global Carbon Budget. Science 2006, 312, 1612-1613. [CrossRef]

5. Zimov, S.A.; Davydov, S.P.; Zimova, G.M.; Davydova, A.I.; Schuur, E.A.G.; Dutta, K.; Chapin, F.S., III. Permafrost carbon: Stock and decomposability of a globally significant carbon pool. Geophys. Res. Lett. 2006, 33, L20502. [CrossRef]

6. Schuur, E.A.G.; Bockheim, J.; Canadell, J.G.; Euskirchen, E.; Field, C.B.; Goryachkin, S.V.; Hagemann, S.; Kuhry, P.; LaFleur, P.M.; Lee, H.; et al. Vulnerability of Permafrost Carbon to Climate Change: Implications for the Global Carbon Cycle. Bioscience 2008, 58, 701-714. [CrossRef]

7. DeConto, R.M.; Galeotti, S.; Pagani, M.; Tracy, D.; Schaefer, K.; Zhang, T.; Pollard, D.; Beerling, D.J. Past extreme warming events linked to massive carbon release from thawing permafrost. Nature 2012, 484, 87-91. [CrossRef]

8. Schuur, E.A.G.; McGuire, A.D.; Schädel, C.; Grosse, G.; Harden, J.W.; Hayes, D.J.; Hugelius, G.; Koven, C.D.; Kuhry, P.; Lawrence, D.M.; et al. Climate change and the permafrost carbon feedback. Nature 2015, 520, 171-179. [CrossRef]

9. Knoblauch, C.; Beer, C.; Liebner, S.; Grigoriev, M.N.; Pfeiffer, E.-M. Methane production as key to the greenhouse gas budget of thawing permafrost. Nat. Clim. Chang. 2018, 8, 309-312. [CrossRef]

10. Zhao, Z.; Zhang, Y.; Liu, L.; Liu, F.; Zhang, H. Recent changes in wetlands on the Tibetan Plateau: A review. J. Geogr. Sci. 2015, 25, 879-896. [CrossRef]

11. $\mathrm{Mu}, \mathrm{C}$; Zhang, T.; Wu, Q.; Peng, X.; Cao, B.; Zhang, X.; Cao, B.; Cheng, G. Editorial: Organic carbon pools in permafrost regions on the Qinghai-Xizang (Tibetan) Plateau. Cryosphere 2015, 9, 479-486. [CrossRef]

12. Ding, J.; Chen, L.; Ji, C.; Hugelius, G.; Li, Y.; Liu, L.; Qin, S.; Zhang, B.; Yang, G.; Li, F.; et al. Decadal soil carbon accumulation across Tibetan permafrost regions. Nat. Geosci. 2017, 10, 420-424. [CrossRef]

13. Mu, C.; Abbott, B.W.; Norris, A.J.; Mu, M.; Fan, C.; Chen, X.; Jia, L.; Yang, R.; Zhang, T.; Wang, K.; et al. The status and stability of permafrost carbon on the Tibetan Plateau. Earth-Sci. Rev. 2020, 211, 103433. [CrossRef]

14. Lu, Z.Q.; Zhu, Y.H.; Zhang, Y.Q.; Wen, H.; Li, Y.H.; Liu, C.L. Gas hydrate occurrences in the Qilian Mountain permafrost, Qinghai Province, China. Cold Reg. Sci. Technol. 2011, 66, 93-104. [CrossRef]

15. Song, Y.; Yang, L.; Zhao, J.; Liu, W.; Yang, M.; Li, Y.; Liu, Y.; Li, Q. The status of natural gas hydrate research in China: A review. Renew. Sustain. Energy Rev. 2014, 31, 778-791. [CrossRef]

16. Wang, X.; Pan, L.; Lau, H.C.; Zhang, M.; Li, L.; Zhou, Q. Reservoir volume of gas hydrate stability zones in permafrost regions of China. Appl. Energy 2018, 225, 486-500. [CrossRef]

17. O'Connor, F.M.; Boucher, O.; Gedney, N.; Jones, C.D.; Folberth, G.A.; Coppell, R.; Friedlingstein, P.; Collins, W.J.; Chappellaz, J.; Ridley, J.; et al. Possible role of wetlands, permafrost, and methane hydrates in the methane cycle under future climate change: A review. Rev. Geophys. 2010, 48, RG4005. [CrossRef]

18. Cui, M.; Ma, A.; Qi, H.; Zhuang, X.; Zhuang, G.; Zhao, G. Warmer temperature accelerates methane emissions from the Zoige wetland on the Tibetan Plateau without changing methanogenic community composition. Sci. Rep. 2015, 5, 11616. [CrossRef]

19. Dean, J.F.; Middelburg, J.J.; Röckmann, T.; Aerts, R.; Blauw, L.G.; Egger, M.; Jetten, M.S.M.; de Jong, A.E.E.; Meisel, O.H.; Rasigraf, O.; et al. Methane Feedbacks to the Global Climate System in a Warmer World. Rev. Geophys. 2018, 56, 207-250. [CrossRef]

20. Yu, L.; Wang, H.; Wang, Y.; Zhang, Z.; Chen, L.; Liang, N.; He, J.-S. Temporal variation in soil respiration and its sensitivity to temperature along a hydrological gradient in an alpine wetland of the Tibetan Plateau. Agric. For. Meteorol. 2020, 282-283, 107854. [CrossRef] 
21. Kuhn, M.; Lundin, E.J.; Giesler, R.; Johansson, M.; Karlsson, J. Emissions from thaw ponds largely offset the carbon sink of northern permafrost wetlands. Sci. Rep. 2018, 8, 9535. [CrossRef] [PubMed]

22. Mu, C.; Li, L.; Wu, X.; Zhang, F.; Jia, L.; Zhao, Q.; Zhang, T. Greenhouse gas released from the deep permafrost in the northern Qinghai-Tibetan Plateau. Sci. Rep. 2018, 8, 4205. [CrossRef]

23. Song, C.; Xu, X.; Sun, X.; Tian, H.; Sun, L.; Miao, Y.; Wang, X.; Guo, Y. Large methane emission upon spring thaw from natural wetlands in the northern permafrost region. Environ. Res. Lett. 2012, 7, 34009. [CrossRef]

24. Mestdagh, T.; Poort, J.; De Batist, M. The sensitivity of gas hydrate reservoirs to climate change: Perspectives from a new combined model for permafrost-related and marine settings. Earth-Sci. Rev. 2017, 169, 104-131. [CrossRef]

25. Maslin, M.; Owen, M.; Betts, R.; Day, S.; Jones, T.D.; Ridgwell, A. Gas hydrates: Past and future geohazard? Philos. Trans. R. Soc. London. Ser. A Math. Phys. Eng. Sci. 2010, 368, 2369-2393. [CrossRef]

26. Wang, P.K.; Zhu, Y.H.; Lu, Z.Q.; Huang, X.; Pang, S.J.; Zhang, S. Gas hydrate stability zone migration occurred in the Qilian mountain permafrost, Qinghai, Northwest China: Evidences from pyrite morphology and pyrite sulfur isotope. Cold Reg. Sci. Technol. 2014, 98, 8-17. [CrossRef]

27. China Meteorological Administration. China Greenhouse Gas Bulletin: The State of Greenhouse Gases in the Atmosphere Based on China and Global Observations until 2019. 2020; Volume 9, pp. 1-5. Available online: http://www.cma.gov.cn/root7/auto13139/ (accessed on 15 February 2022). (In Chinese)

28. Luo, M.; Huang, H.; Zhang, P.; Wu, Q.; Chen, D. Origins of gas discharging from the Qiangtang Basin in the northern QinghaiTibet Plateau, China: Evidence from gas compositions, helium, and carbon isotopes. J. Geochem. Explor. 2014, 146, $119-126$. [CrossRef]

29. Sun, Z.J.; Yang, Z.B.; Mei, H.; Qin, A.H.; Zhang, F.G.; Zhou, Y.L.; Zhang, S.Y.; Mei, B.W. Geochemical characteristics of the shallow soil above the Muli gas hydrate reservoir in the permafrost region of the Qilian Mountains, China. J. Geochem. Explor. 2014, 139, 160-169. [CrossRef]

30. Zhang, S.Y.; Zhang, F.G.; Shi, Z.M.; Qin, A.H.; Wang, H.Y.; Sun, Z.J.; Yang, Z.B.; Zhu, Y.H.; Pang, S.J.; Wang, P.K. Sources of seasonal wetland methane emissions in permafrost regions of the Qinghai-Tibet Plateau. Sci. Rep. 2020, 10, 7520. [CrossRef]

31. Zhang, S.Y.; Yang, F.; Zhang, F.G.; Shi, Z.M.; Yang, Z.B.; Zhou, Y.L.; Wang, H.Y. Study on methane emission and isotopic characteristics of wetland in permafrost area of Qinghai Tibet Plateau. Mod. Geol. 2018, 32, 1089-1096. [CrossRef]

32. Whiticar, M.J. Carbon and hydrogen isotope systematics of bacterial formation and oxidation of methane. Chem. Geol. 1999, 161, 291-314. [CrossRef]

33. Barker, J.F.; Fritz, P. Carbon isotope fractionation during microbial methane oxidation. Nature 1981, 293, 289-291. [CrossRef]

34. Zhou, Y.; Guo, D.; Qiu, G.; Cheng, G.; Li, S. Geocryology in China; Science Press: Beijing, China, 2000. (in Chinese)

35. Wen, H.J.; Shao, L.Y.; Li, Y.H.; Lu, J.; Zhang, S.L.; Wang, W.L.; Huang, M. Structural outline and stratigraphic framework of Juhugeng mining area in Muli Coalfield, Tianjun County, Qinghai Province. Geol. Bulletin. 2011, 30, 1823-1828. [CrossRef]

36. Lu, Z.Q.; Rao, Z.; He, J.X.; Zhu, Y.H.; Zhang, Y.Q.; Liu, H.; Wang, T.; Xue, X.H. Geochemistry of drill core headspace gases and its significance in gas hydrate drilling in Qilian Mountain permafrost. J. Asian Earth Sci. 2015, 98, 126-140. [CrossRef]

37. Wang, P.K.; Zhu, Y.H.; Lu, Z.Q.; Guo, X.W. Lithology and distribution characteristics of gas hydrate in permafrost area of Qi-lian Mountain. Geol. Bulletin. 2011, 30, 1839-1850.

38. Li, B.; Sun, Y.H.; Guo, W.; Shan, X.L.; Wang, P.K.; Pang, S.J.; Jia, R.; Zhang, G.B. The mechanism and verification analysis of permafrost-associated gas hydrate formation in the Qilian Mountain, Northwest China. Mar. Pet. Geol. 2017, 86, 787-797. [CrossRef]

39. Zhu, Y.H.; Zhang, Y.Q.; Wen, H.J.; Lu, Z.Q.; Jia, Z.Y.; Li, Y.H.; Li, Q.H.; Liu, C.L.; Wang, P.K.; Guo, X.W. Gas Hydrates in the Qilian Mountain Permafrost, Qinghai, Northwest China. Acta Geol. Sin. 2010, 84, 1-10. [CrossRef]

40. Lu, Z.; Zhu, Y.; Zhang, Y.; Wen, H.; Li, Y.; Jia, Z.; Wang, P.; Li, Q. Study on genesis of gases from gas hydrate in the Qilian Mountain Permafrost, Qinghai. Geoscience 2010, 24, 581-588. [CrossRef]

41. Keeling, C.D. The concentration and isotopic abundances of atmospheric carbon dioxide in rural areas. Geochim. Cosmochim. Acta 1958, 13, 322-334. [CrossRef]

42. Miller, J.B.; Tans, P.P. Calculating isotopic fractionation from atmospheric measurements at various scales. Tellus B Chem. Phys. Meteorol. 2003, 55, 207-214. [CrossRef]

43. Campeau, A.; Wallin, M.B.; Giesler, R.; Löfgren, S.; Mörth, C.-M.; Schiff, S.; Venkiteswaran, J.J.; Bishop, K. Multiple sources and sinks of dissolved inorganic carbon across Swedish streams, refocusing the lens of stable C isotopes. Sci. Rep. 2017, 7, 9158. [CrossRef] [PubMed]

44. Liu, C.; He, X.; Meng, Q.; Ye, Y.; Zhu, Y.; Lu, Z. Carbon and hydrogen isotopic compositions characteristics of the released gas from natural gas hydrates in the Qilian Mountain Permafrost. Rock Miner. Anal. 2012, 31, 489-494. [CrossRef]

45. Liu, C.L.; Meng, Q.G.; He, X.L.; Li, C.F.; Ye, Y.G.; Lu, Z.Q.; Zhu, Y.H.; Li, Y.H.; Liang, J.Q. Comparison of the characteristics for natural gas hydrate recovered from marine and terrestrial areas in China. J. Geochem. Explor. 2015, 152, 67-74. [CrossRef]

46. Cheng, B.; Xu, J.B.; Lu, Z.Q.; Li, Y.H.; Wang, W.C.; Yang, S.; Liu, H.; Wang, T.; Liao, Z.W. Hydrocarbon source for oil and gas indication associated with gas hydrate and its significance in the Qilian Mountain permafrost, Qinghai, Northwest China. Mar. Pet. Geol. 2018, 89, 202-215. [CrossRef]

47. Dai, J.X.; Ni, Y.; Huang, S.; Liao, F.; Yu, C.; Gong, D.; Wu, W. Significant function of coal-derived gas study for natural gas industry development in China. Nat. Gas Geosci. 2014, 25, 1-22. [CrossRef] 
48. Dai, J.X.; NI, Y.Y.; Huang, S.P.; Peng, W.L.; Han, W.X.; Gong, D.Y.; Wei, W. Genetic types of gas hydrates in China. Pet. Explor. Dev. 2017, 44, 887-898. [CrossRef]

49. Ganesan, A.L.; Stell, A.C.; Gedney, N.; Comyn-Platt, E.; Hayman, G.; Rigby, M.; Poulter, B.; Hornibrook, E.R.C. Spatially Resolved Isotopic Source Signatures of Wetland Methane Emissions. Geophys. Res. Lett. 2018, 45, 3737-3745. [CrossRef]

50. Schwietzke, S.; Sherwood, O.; Bruhwiler, L.M.P.; Miller, J.; Etiope, G.; Dlugokencky, E.J.; Michel, S.E.; Arling, S.S.J.B.M.V.A.; Vaughn, B.H.; White, J.; et al. Upward revision of global fossil fuel methane emissions based on isotope database. Nature 2016, 538, 88-91. [CrossRef]

51. Kato, T.; Yamada, K.; Tang, Y.H.; Yoshida, N.; Wada, E. Carbon isotopic signature reveals the geographical trend in methane consumption and production pathways in alpine ecosystems over the Qinghai-Tibetan Plateau. Isot. Environ. Health Stud. 2017 53, 597-609. [CrossRef]

52. Fisher, R.E.; France, J.L.; Lowry, D.; Lanoisellé, M.; Brownlow, R.; Pyle, J.A.; Cain, M.; Warwick, N.; Skiba, U.M.; Drewer, J.; et al. Measurement of the $13 \mathrm{C}$ isotopic signature of methane emissions from northern European wetlands. Glob. Biogeochem. Cycles 2017, 31, 605-623. [CrossRef]

53. Kato, T.; Yamada, K.; Tang, Y.H.; Yoshida, N.; Wada, E. Stable carbon isotopic evidence of methane consumption and production in three alpine ecosystems on the Qinghai-Tibetan Plateau. Atmos. Environ. 2013, 77, 338-347. [CrossRef]

54. Ji, M.K.; Kong, W.D.; Liang, C.; Zhou, T.Q.; Jia, H.Z.; Dong, X.B. Permafrost thawing exhibits a greater influence on bacterial richness and community structure than permafrost age in Arctic permafrost soils. Cryosphere 2020, 14, 3907-3916. [CrossRef]

55. Mackelprang, R.; Waldrop, M.P.; DeAngelis, K.M.; David, M.M.; Chavarria, K.L.; Blazewicz, S.J.; Rubin, E.M.; Jansson, J.K. Metagenomic analysis of a permafrost microbial community reveals a rapid response to thaw. Nature 2011, 480, 120-368. [CrossRef]

56. Chen, Y.L.; Liu, F.T.; Kang, L.Y.; Zhang, D.Y.; Kou, D.; Mao, C.; Qin, S.Q.; Zhang, Q.W.; Yang, Y.H. Large-scale evidence for microbial response and associated carbon release after permafrost thaw. Glob. Chang. Biol. 2021, 27, 3218-3229. [CrossRef] [PubMed]

57. Gruen, D.S.; Wang, D.; Könneke, M.; Begüm, D.T.; Stewart, L.C.; Goldhammer, T.; Holden, J.F.; Hinrichs, K.-U.; Ono, S. Experimental investigation on the controls of clumped isotopologue and hydrogen isotope ratios in microbial methane. Geochim. Cosmochim. Acta 2018, 237, 339-356. [CrossRef]

58. McCalley, C.K.; Woodcroft, B.; Hodgkins, S.B.; Wehr, R.; Kim, E.-H.; Mondav, R.; Crill, P.; Chanton, J.P.; Rich, V.I.; Tyson, G.; et al. Methane dynamics regulated by microbial community response to permafrost thaw. Nature 2014, 514, 478-481. [CrossRef] 